FOTrREu, E. (1980) A study of violent behaviour among patients in psychlatric hospitals. British Journal of Psychiatry. 138, 216-221.

Jackson G. GATER, D. TANTAM D. et al (1993) A new community mental health team based in primary care: a description of the service and its effect on service use in the first year. British Journal of Psychiatry. 162, 375384

LEwS, G \& APPLEBY, L. (1988) Personality disorder: the patients psychiatrists dislike. Brttish Joumal of Psychiatry, 165, 44-49.

NoBle, P \& RODGers, S (1984) Violence by psychlatric inpatients. Brtish Journal of Psychiatry, 145, 384-390.
RoYal CoLnjae of Psychiatrists (1991) Report of the Colleglate Trainees' Committee Working Party on training of junior psychiatrists with respect to violent incidents. Psychiatric Bulletin, 16, 243-246.

Jane F. Whittaker, Registrar; and Louis Appleby, Senior Lecturer, Department of Psychiatry, Withington Hospital, West Didsbury, Manchester M20 8LR

\title{
Community care for people with learning disabilities: deficits and future plans
}

\author{
Nick Bouras, Geraldine Holt and Shaun Gravestock
}

\begin{abstract}
The challenge facing services for people with leaming disobilities is to create the environment in which clients have the best quality of lite without preconception. The heterogenous nature of people with leaming discablities requires diverstly of care provisions senstitive to their individual needs. The difierent demonstration and presentation of their mental health needs has inluenced the development of services and ditierent models of speclallst services have emerged with local variations. There is still, however, a great deal of contustion on both ideological and service dellvery lovel. Athough services for people with leaming discbillties hove succeeded in resettiling people in the community and supporting them in doveloping odcptive skills, uniortunately these successes are not matched by equally effective and efficient services to those with mental heatth needs.
\end{abstract}

The functioning of people with learning disabilities is affected by many factors other than their intellectual impairments. Their ability to communicate and their social competency also influence their behaviour and adjustment. People with learning disabilities may require support to live an independent life but the challenge facing services is to create the environment that will provide them with the best quality of life while maximising developmental opportunities.

\section{Community care}

Successive policy initiatives since the 1970 s have led to the resettlement of people with learning disabilities from long-stay hospitals into the community. In the 1980 s issues arising from the 'normalisation' (social valorisation), consumers' rights, self-advocacy and quality assurance movements have radically influenced the service models developed for people with learning disabilities. The focus on ordinary housing also highlighted the role of the housing departments of local authorities, housing associations and voluntary organisations while increasing the use of social security benefits. The Community Care Act (Department of Health, 1989) consolidated the interface between health, social services and voluntary agencies.

People with learning disabilities vary from those who have a mild degree of intellectual disability but are physically normal, to those who have severe and multiple disabilities requiring specialist care. Unfortunately none of the existing classification systems provide a satisfactory framework to assess the service requirements of people with learning disabilities (Anness et al, 1991). 
This has resulted in confusion about service provision, particularly for those people falling in the 'grey area' between normal functioning and disabilities.

\section{Mental health needs}

When resettlement started, some of the service planners thought that the psychiatric needs of people with learning disabilities would be met by the generic mental health services. This view was partly based on the normalisation ideology, implying that people with learning disabilities should have access to mainstream services. Meanwhile, the resources tied up in several mental handicap hospitals could be used to promote skills development and increasing independent life styles for people with learning disabilities. However, it was soon realised that this view was not realistic. First, the complex behaviour problems of people with severe learning disabilities could not be managed by generic psychiatric services and some specialist provision was essential. Secondly, no attempt was made to negotiate the associated service issues and problems between mental health and learning disabilities service providers.

Some reasons why the generic psychiatric services have been unwilling to provide psychiatric care for people with mild and moderate learning disabilities are that generic psychiatric services felt that they lacked knowledge, training, skdlls and facilities to meet the needs of people with learning disabilities formerly cared for by the specialist learning disabilities services. Furthermore, the funding implications for the generic psychiatric services were not discussed and negotiated.

The problems have become more complicated by the lack of clear operational policies and service agreements; vague definitions of who is entitled to access which service; professional rivaliries and constrained budgets.

\section{Service models}

Over the last ten years the following models of specialised mental health services for those with learning disabilities have merged with several local variations.

(a) A separate specialised comprehensive provision including domiciliary, assessment, treatment and continuing care services for the whole range of people with learning disabilities (Day. 1994). This model proposes specialised in-patient psychiatric units to meet the needs of people with mental illness and behaviour problems, those who offend and elderly people with learning disabilities. This service model is seen within the large hospital-based provision as locally based units would be unable to provide a full range of treatment settings or to cope with severely disturbed people. Smaller local units also have problems with medical cover, staff support, and occupational and recreational provision (ibid).

(b) A community-based specialist psychiatric service integrated mainly with the learning disabilities services (Bicknell, 1985). This model has the advantages of being within the community but risks being marginalised by both learning disabilities and mental health services. The latter leads to difficulties in gaining access to in-patient psychiatric facilities. The result can be providing mainly an advisory service with limited clinical involvement.

(c) A community based specialised psychiatric service, integrated with the mainstream psychiatric services (Bouras \& Drummond, 1992; Bouras et al, 1993). This model has been gaining acceptance as an appropriate service delivery system with two main outcomes. First, the clients experience less disruption and distress as the specialist input they require is usually provided at home. The second is that the model enables local services to develop their own skdlls in supporting and managing clients with complex needs.

There are circumstances where residential services or families are unable to continue supporting a particular individual and a 'back-up' admission facllity is then required. In our model, we have been using acute and medium-stay generic psychiatric inpatient beds as needed to effectively return the client to the community. Close collaboration with clinical psychologists, therapists, other professional and support staff is maintained during clinical interventions.

(d) Separate 'challenging behaviour' services have been developed and 
continue growing as part of learning disabilities services. Challenging behaviour services are mainly led by clinical psychologists and are predominantly peripatetic, although there are also a few residential units. Nonetheless, whether or not challenging behaviour arises from an underlying mental illness, psychlatric assessment is usually needed and input should also be provided by specialist psychiatric services.

\section{Service responses}

There is still a great deal of confusion at both ideological and service delivery levels. The Mansell report (Department of Health, 1993) recently commissioned by the central government strongly recommends the development of local services "within the mainstream services".

This is certainly a step forward but important concepts remain unclear. The Mansell report refers mainly to "challenging behaviour" and not to mental illness. Furthermore the recommendation of developing local services within the "mainstream services" has been interpreted by both learning disabilities and mental health services as implying that the other party has responsibility for developing "challenging behaviour" services. The Department of Health Advisory Group has issued a statement clarifying that specialist services in learning disabilities will be needed and that the organisation of learning disability psychiatry should be integrated with general psychiatry to ensure that people with learning disability have access to the full range of psychiatric services (Tizard Centre, 1994).

People with learning disabilities and mental health needs present complex challenges for the provision of services and care delivery. They require both acute and ongoing specialist psychiatric assessment, treatment and support to minimise residual deficits and functional impairments.

Services for people with learning disabilities have been in the forefront of community care developments. They have preceeded community care services for people with psychiatric illness and have pioneered concepts of ordinary housing, individual planning and care co-ordination.
There is a danger that unless satisfactory provisions for their mental health needs are agreed, people with learning disabilities and mental health problems will become the responsibility of the generic psychiatric services by default.

Urgent negotiations between learning disabilities and mainstream mental health services are needed to begin clarifying responsibilities and funding arrangements. Specialist mental health services for people with learning disabilities should be linked with any local learning disabilities and mental health services. In areas where long stay hospitals have closed, the specialist mental health services in learning disabilities have shrunk and tend to be marginalised (SETHRA, 1993).

It is our personal opinion, based on over ten years' experience, that community specialist psychiatric services for people with learning disabilities should become operationally and managerially linked to the generic mental health services with access to in-patient and forensic beds. Challenging behaviour service initiatives mainly for people with severe learning disabilities should also be linked with the specialist mental health service in learning disabilities. However, agreed operational policies for multi-professional work will be necessary.

Residential and day care facilities will continue playing a decisive role supporting people with learning disabilities to live in the community. Health service authorities have continuing responsibilities to provide clinical input to community residential and day care facilities. With the new community care funding arrangements, the availability of affordable housing and appropriate private and voluntary learning disabilities service providers will also be vital. General practitioner fund-holders may use their increasing purchasing powers to influence future learning disabilities service models. Training community support staff will also be essential.

Community care philosophies have been accompanied by increasing demands to monitor the costs and quality of services. Managers are keen to develop user outcome indicators that relate to service objectives, structure and process. This would allow purchasers and providers to assess the cost-effectiveness of learning disabilities services (Knapp et al, 1992). The challenge 
facing multiprofessional services will be how to avoid cost rather than quality becoming the crucial service delivery issue. At this stage it is impossible to predict the future influence of internal markets on resettlement programmes and access to specialised community learning disabilities services usually provided as high risk, high cost and low volume packages (Glover et al, 1993).

Defining individual and local population met/unmet needs, quality of life as well as measuring the cost-effectiveness of services will remain shared challenges for users, purchasers and providers. Local service ecological factors will be increasingly recognised such as the varying quality and resources of local authority, primary and secondary health care services in inner London (Tomlinson, 1992).

Providing quality services to people with learning disabilities and mental health needs living in fragmented, socially deprived and multi-cultural inner-city communities remains a complex problem. By operating a coherent specialist service model focused on adults with learning disabilities and mental health needs, we hope to avoid the fragmentation and confusions associated with rapidly changing external service environments.

\section{References}

AnNess, V., Bhat. A., Bouras, N., CalluAs, M. et al (1991) A mult-aspect assessment for people with mental handicap. Psychiatric Bullettr, 18, 146.
BickNeuL J. (1985) The mental handicap service. In Caring for Mentally Handicapped People in the Community (eds. Sines, D. and Bicknell, J.) London: Harper \& Row.

BOURAS. N. \& DRUMmOND, C. (1992) Behaviour and psychiatric disorders of people with mental handicaps. itving in the community. Joumal of Intellectual Disability Research, 36, 349-357.

- KON, Y.. \& DRUMMOND, C. (1993) Return to community: medical and psychiatric needs of adults with mental handicap. Journal of Intellectual Disablity Research, 37. 177-182.

DAY, K. (1994) Psychlatric services in mental retardation: generic or specialised provision? In Mental Health in Mental Retardation, (ed. Bouras, N.) Cambridge Untversity Press.

Department of HEalth (1989) Caring for People: Community Care in the Next Decade and Beyond. London: HMSO.

- (1993) Challenging Behavtours and/or Mental Health Needs of People with Leaming Disabulities. (Mansell Report). London: HMSO.

GLOVER, G. R, ROHDE, J. \& FARMER, R. D. T. (1993) Is money following the clients with learning disabilities? Brttish Medical Journal, S06, 987-990.

Knapp, M., Cambridge, P., Thomason, C., Begecham, J. et al (1992) Care in the Community: Challenge and Demonstration. Canterbury: Personal Soclal Services Research Unit, Untversity of Kent.

SETHRA (1993) The Mental Health Needs of People with Learning Disabalties. Report of a Working Group by South East Thames Reglonal Health Authority. Bexhill.

TZARD CENTRE (1994) Mansell Report Implementation Network Newsletter, No 2, 27 May 1994. Untversity of Kent at Canterbury.

Tominson, B. (1992) Report of the Inquity into London's Health Service, Medical Education and Research London: HMSO.

*Nick Bouras, Consultant Psychiatrist, Geraldine Holt, Consultant Psychiatrist and Shaun Gravestock, Locum Consultant Psychiatrist, Division of Psychiatry, UMDSGuy's Hospital, London SE1 9RT

*Correspondence 